\title{
Describing dispersal under habitat constraints: A randomization approach in lesser kestrels
}

\author{
David Serrano ${ }^{\times}$, Martina Carrete, Jose L. Tella \\ Department of Conservation Biology, Estación Biológica de Donana (CSIC), Pabellón del Perú, \\ Avda. María Luisa s/n, 41013 Sevilla, Spain
}

\begin{abstract}
Animal dispersal is usually studied with capture-mark-reencounter data, which provide information on realized dispersal but rarely on underlying processes. In this context, the unreliable assumption of all habitat being available is usually made when describing and analysing dispersal patterns. However, actual settlement options may be constrained by the spatial distribution of appropriate patches, so an important task to understand movement patterns is to adequately describe dispersal when the dispersers' options are constrained by the sites that are available to them. Using a long-term monitored population of the migratory lesser kestrel, we show how randomization procedures can be used to describe dispersal strategies in such situations. This species breeds colonially in discrete patches, most individuals (83\%) disperse from their natal colony, and dispersers tend to move short distances (median $1 / 47.2 \mathrm{~km}$ ). Observed patterns (natal dispersal rates and median dispersal distances of birds emigrating from their natal colony) were compared with those expected from two null models of random settlement of individuals: in any colony available in the whole population, or within the subpopulation (cluster of colonies) of origin. Our simulations indicate that philopatry to the natal colony was much higher than expected under both null expectations, and observed distances were much lower than expected in the whole population. When individuals were constrained to settle within their natal subpopulation in the simulations, dispersal distances were longer than expected in females, but were higher or lower in males depending on year. Dispersal was not only constrained by the spatial distribution of settlement options, but specific hypotheses arise that can be helpful to design and conduct further research. These results challenge previous interpretations of observed dispersal patterns, which may not reflect free decisions of individuals but environmental or social constraints. We suggest using simulation procedures as a routine to advance in the understanding of dispersal ecology and evolution.
\end{abstract}

\section{Zusammenfassung}

Die Ausbreitung von Tieren wird normalerweise uber Fang-Wiederfang-Daten untersucht, die zwar Informationen uber die tatsachliche Ausbreitung liefern, jedoch wenig uber die zugrundeliegenden Prozesse aussagen. In diesem Zusammenhang wird normalerweise die unwahrscheinliche Annahme getroffen, dass samtliche Habitate zur Verfugung stehen, wenn Ausbreitungsmuster beschrieben und analysiert werden. Die tatsachlichen Ansiedlungsmgolichkeiten sind jedoch durch die raumliche Anordnung geeigneter Flachen beschrankt. Fur das Verstandnis der

\footnotetext{
${ }^{\times}$Corresponding author. Tel.: +34 954232340; fax: +34954621125.

E-mail address: serrano@ebd.csic.es (D. Serrano).
} 
Bewegungsmuster ist es daher eine wichtige Voraussetzung, die Ausbreitung adaquat zu beschreiben, wenn die Ausbreitungsmoglichkeiten durch die zur Verfugung stehenden Flachen beschrankt sind. Unter Nutzung einer langfristig untersuchten Population des ziehenden Rotelfalkens beschreiben wir, wie Randomisierungsprozeduren genutzt werden konnen, um die Ausbreitungsstrategien in solchen Situationen zu beschreiben. Die Art brutet in Kolonien an diskreten Orten, die meisten Individuen (83 \%) verlassen die Brutkolonie und die wandernden Vogel bewegen sich nur eine kurze Distanz (Median 1/4 7,2 km). Die beobachteten Muster (Ausbreitungsraten und die Mediane der Ausbreitungsdistanzen von Vogeln, die ihre Geburtskolonie verlassen) wurden mit denen verglichen, die aufgrund von zwei Null-Modellen bei zufalligen Besiedlungen durch die Individuen erwartet wurden: in jede Kolonie, die in der Population zur Verfugung steht, oder innerhalb der Herkunfts-Subpopulation (ein Cluster von Kolonien). Unsere Simulationen weisen darauf hin, dass die Standorttreue in den Geburtskolonien viel hoher war als aufgrund beider Null-Modelle erwartet wurde und dass die beobachteten Distanzen in der gesamten Population sehr viel geringer als erwartet waren. Wenn die Individuen in dem Modell darauf beschrankt waren, in der HerkunftsSubpopulation zu siedeln, dann waren die Ausbreitungsdistanzen großer als erwartet bei den Weibchen, jedoch in Abhangigkeit vom Jahr bei den Mannchen großer oder geringer. Die Ausbreitung war nicht nur durch die raumliche Verteilung der Ansiedlungsmoglichkeiten begrenzt, aber es ergeben sich spezifische Hypothesen, die hilfreich bei der Planung und Durchfuhrung weiterer Forschung sind. Diese Ergebnisse stellen vorangegangene Interpretationen der beobachteten Ausbreitungsmuster in Frage, die nicht freie Entscheidungen von Individuen widerspiegeln, sondern soziale oder Umwelteinschrankungen. Wir schlagen vor, Simulationsprozeduren als Routine zu nutzen, um das Verstandnis der Ausbreitungsokologie und Evolution zu fordern.

r 2007 Gesellschaft fur Okologie. Published by Elsevier GmbH. All rights reserved.

Keywords: Dispersal; Falco naumanni; Monte Carlo simulations; Philopatry; Randomization; Settlement

\section{Introduction}

Dispersal is a key process in ecology, evolutionary and conservation biology, and therefore factors governing movement and dispersal in animals have long interested ecologists (Clobert, Danchin, Dhondt, \& Nichols, 2001). Research has shown that philopatry may provide benefits to individuals such as optimal inbreeding and familiarity with foraging areas, predators and conspecifics, while avoiding traveling costs. Yet emigration, too, can confer benefits such as relaxing (kin) competition, avoiding inbreeding, or escape from degrading environments (see reviews in Dieckmann, O’Hara, \& Weisser, 1999; Johnson \& Gaines, 1990). Thus, both philopatry and dispersal may be optimal and evolutionary stable strategies depending on the balance between costs and benefits faced by organisms in different ecological and evolutionary scenarios. Nowadays, there is strong evidence that many factors may act in concert to affect both dispersal rates and distances covered by dispersers. It is widely accepted that dispersal is a condition-dependent feature related to phenotypic and behavioural traits (Bowler \& Benton, 2005). At the same time, dispersal is also affected by environmental circumstances, so it is seen as a plastic trait that can differ among populations of the same species depending on the ecological, social or demographic context. For example, dispersal rates may be regulated by densitydependent mechanisms such as competition for resources (Matthysen, 2005; Serrano \& Tella, 2007) or conspecific attraction (Serrano, Forero, Donazar, \&
Tella, 2004; Stamps, 2001), or may differ between populations depending on their degree of fragmentation and isolation (Peacock \& Ray, 2001; Serrano \& Tella, 2003). Recent evidence also indicates that at least in some vertebrates dispersal propensity is partly heritable and exhibits substantial additive genetic variance (Hansson, Bensch, \& Hasselquist, 2003; Krackow, 2003; Pasinelli, Schiegg, \& Walters, 2004), so plasticity in dispersal behaviours may be reaction norms to underlying genetic propensities. Hence, variation in fitness related to dispersal decisions of individuals (e.g., Forero, Donazar, \& Hiraldo, 2002; Part, 1991; Pasinelli et al., 2004) can select for dispersal behaviour as a life-history strategy on an evolutionary timescale (Bowler \& Benton, 2005).

In this context, dispersal may be interpreted as an adaptive behaviour evolved under natural selection (e.g. Weatherhead \& Forbes, 1994; Paradis, Baillie, Sutherland, \& Gregory, 1998), with the observed frequencies of philopatry and dispersal reflecting the balance between the costs and benefits of each strategy. However, dispersal is usually studied with capturemark-reencounter data (Bennetts, Nichols, Lebreton, Pradel, \& Hines, 2001), from which it is often difficult to distinguish between different behavioural and ecological mechanisms that might produce the same realized dispersal pattern (Doerr \& Doerr, 2005). For example, an important issue is that dispersal decisions can be influenced by spatial variation in the abundance and distribution of available habitats, which may complicate the evolutionary interpretation of dispersal patterns. 
An extreme possibility departing from an optimal balance between costs and benefits would be a random dispersal pattern only constrained by the spatial distribution of resources needed for breeding. Thus, an important step towards understanding dispersal ecology and evolution is to adequately describe dispersal patterns when the dispersers' options are constrained by the sites available to them.

Null models are widely applied in ecological research (e.g. Harvey, Colwell, Silvertown, \& May, 1983), and randomization procedures are commonly employed to generate frequency distributions and tests of hypotheses. As early as 1979, Greenwood, Harvey, and Perrins (1979) compared their dispersal data on great tits, Parus major, to that expected under a null model of random movement between nest boxes. These procedures, however, have been largely overlooked and randomization approaches have rarely been used in studies of animal dispersal (Peacock \& Ray, 2001; van Tienderen \& van Noordwijk, 1988; Winkler, Wrege, Allen, Kast, Senesac et al., 2005). Here, we show how simple randomization procedures can be used to describe dispersal patterns when dispersal decisions are constrained by the spatial distribution of dispersal options. For this purpose, we make use of detailed information on natal dispersal performance from a long-term monitored population of lesser kestrels, Falco naumanni (Serrano et al., 2004; Serrano, Tella, Donazar, \& Pomarol, 2003; Serrano, Tella, Forero, \& Donazar, 2001; Serrano \& Tella, 2003), and compare observed with expected dispersal patterns under random settlement. We have shown elsewhere that most lesser kestrels (83\%) dispersed from their natal colony for first breeding (Serrano et al., 2003), so it was tempting to conclude that emigration from the natal environment is beneficial in this species and thus evolution has promoted high rates of natal dispersal. Nonetheless, the distribution of dispersal distances (ranging from 0.1 to $136.5 \mathrm{~km}$ ) was markedly leptokurtic (median $1 / 4$ $7.23 \mathrm{~km}, \mathrm{~N} \mathrm{1/4} 621$, Serrano et al., 2003), indicating that dispersers were prone to settle near their natal areas. These conclusions substantially change when we compare actual dispersal patterns with those resulting from random movements of individuals among the available breeding-site options.

\section{Methods}

\section{Study population and field procedures}

Lesser kestrels are long-distance migratory, facultative colonial falcons inhabiting traditionally farmed, open areas in the Western Paleartic. Our study was carried out in the Ebro Valley (ca. $10000 \mathrm{~km}^{2}$ ), in
Northeastern Spain, where demography and dispersal of the whole lesser kestrel population was intensively monitored between 1993 and 2000 (see Serrano et al., 2001, 2003, 2004; Serrano, Oro, Ursua, \& Tella, 2005; Serrano \& Tella, 2003, 2007). In the study area, all kestrels bred in abandoned farmhouses that attracted both solitary pairs and colonies of 2-43 pairs. Each year, the distribution of buildings occupied by at least one pair of lesser kestrels (thereafter “colonies") was determined by surveys during which almost every suitable building was visited. The whole population size increased from 224 pairs living in 78 colonies in 1993 to 787 pairs and 180 colonies in 2000 . This population was spatially structured in a variable number of subpopulations composed by well-delimited clusters of colonies which tended to meet at the end of the study. The number of subpopulations also increased from 4 in 1993 to 14 in 2000 (see Serrano and Tella, 2003 for further details).

Nearly all nests in the population were annually checked from April to July to obtain breeding parameters and band the nestlings. A total of 4901 fledglings resulted individually marked with a plastic colour band engraved with an alphanumeric code that could be read at distance with spotting scopes. Banded birds were annually identified in all colonies of the population from late February to obtain dispersal information. It is worth noting that the maximum distance between colonies $(210 \mathrm{~km})$ was much longer than maximum dispersal distances observed $(136.5 \mathrm{~km})$, and that only one case of emigration to other populations was detected during the study period (to Villena, the nearest population, located about $250 \mathrm{~km}$ South; M. Alberdi, pers. com.). This, together with the fact that intensive banding and band reading was made in the whole study area and in neighbouring populations, minimizes the potential bias in dispersal patterns arising from limited study areas (see Serrano et al., 2005 for more details).

\section{Randomization procedures}

Here we studied natal dispersal, i.e. the movement between the place of birth and the first breeding site (Greenwood \& Harvey, 1982). We used Monte Carlo simulations (Manly, 1991) to evaluate the probability that observed natal dispersal patterns could have occurred by chance, and thus if dispersal patterns in this species were only constrained by the spatial distribution of breeding sites. Since most males and an important portion of females recruited when 2 years old into the breeding population (unpubl. data), we analyzed recruitment data from 1995 to 2000 in order to avoid biases in the age of first-breeders derived from the start of the study. When returning from their wintering quarters, lesser kestrels could hypothetically follow two 
alternative strategies. One plausible scenario is that they returned to the Ebro Valley and settled in any colony of the population. To test this possibility, we randomly assigned each individual to a colony occupied during the year of recruitment in the whole population. This procedure is conservative, since more than $90 \%$ of the buildings were unoccupied but suitable for settling throughout the study period (Serrano et al., 2003). Given that lesser kestrel colonies in the study area were clumped in subpopulations, another possibility could be that birds returned to their natal subpopulation and, once there, settled in any colony within this subpopulation. Thus, we performed a second analysis where we constrained the settlement of individuals to the subpopulation of origin, randomly assigning each individual to one of the existing colonies in the year of recruitment.

For each year, simulations of the two null models were repeated 1000 times and compared with (1) the observed patterns of dispersal rates (\% of individuals that dispersed from their natal colony), and (2) the observed patterns of dispersal distances (Euclidean distances from the natal to the settlement colony for birds that dispersed from their natal colony). Dispersal rates (or the reverse, philopatry rates) and dispersal distances were analyzed separately since they potentially resulted from behavioural decisions that are affected by different ecological and social factors (Serrano et al., 2001, 2003) and both could subject to selection (Bowler \& Benton, 2005). Given that natal dispersal is sex-biased in this population (Serrano et al., 2003; Serrano \& Tella, 2003), males and females were analyzed separately. Tests of significance were generated by counting the number of randomized cases that resulted in an equal or larger/smaller value than the observed frequency of philopatry or dispersal distance, and then divided by 1000 (i.e. the total number of randomizations).

\section{Results}

\section{Dispersal rates}

Despite of the high rates of natal dispersal observed (83\% of individuals, see Serrano et al., 2003), our simulations showed that lesser kestrels recruited in their natal colony more frequently than would be expected by chance (Fig. 1). Frequency of expected philopatry was much lower than that observed in all Monte Carlo simulations for both males and females (all p-values O0.001). When we repeated the analyses randomly assigning each individual to a colony within its natal subpopulation, the observed philopatry also differed significantly from a random pattern of settlement in all years of study for males (all p-values O0.001), and in 4

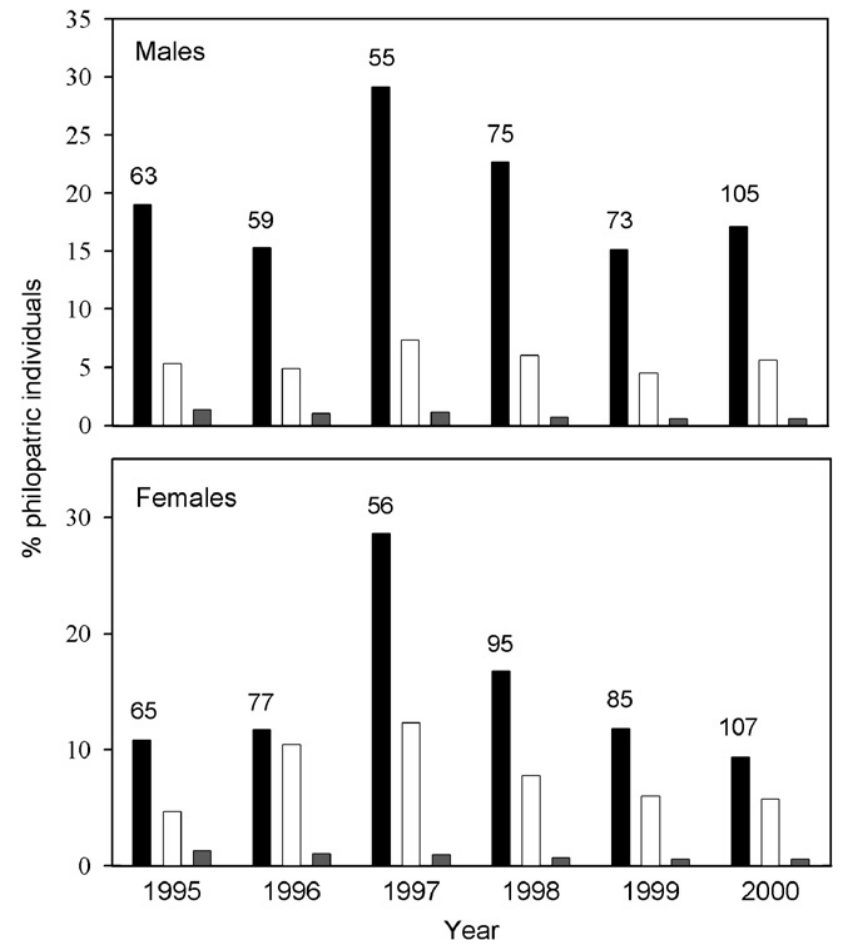

Fig. 1. Values of philopatry to the natal colony observed (black bars) and expected under two null models of random distribution of individuals in (a) the whole population (grey bars), and (b) within the natal subpopulation (white bars). Expected frequencies are based on the number of colonies present in the year of recruitment. Sample sizes above black bars indicate the number of birds recruited in the population each year.

out of 6 years in the case of females (all p-values 0.014 except for 1996, p 1/4 0.41, and 2000, p 1/4 0.07), although the trend was similar in these 2 non-significant years (Fig. 1). Consequently, if we adopt random settlement in either the whole population or the subpopulation of origin as null hypotheses to test whether individuals show philopatric strategies, we may conclude that they tend to settle in their natal colonies in spite of the high rates of realized dispersal observed.

\section{Dispersal distances}

Random models for median dispersal distances within the whole population showed that dispersers tended to settle at distances from their birth colonies which were 2-6 times closer than expected, with similar trends for males and females (all p-valuesO0.0001, Table 1). However, when models were run within the natal subpopulations, some differences appeared (Fig. 2). While females mainly settled in colonies farther from their natal colonies than expected, the pattern for males was highly variable (Fig. 2). In 3 years (1995, 1996 and 1999), males settled in colonies located at shorter 
Table 1. Median (range) dispersal distances in km observed for non-philopatric lesser kestrels compared with random dispersal distances (2.5 and 97.5 percentiles) in the whole population

\begin{tabular}{|c|c|c|c|c|}
\hline \multirow[t]{2}{*}{ Year } & \multicolumn{2}{|l|}{ Males } & \multicolumn{2}{|l|}{ Females } \\
\hline & Observed & Random & Observed & Random \\
\hline 1995 & $\begin{array}{l}4.79(0.2-29.2) \\
n 1 / 451\end{array}$ & 9.60-18.14 & $\begin{array}{l}7.00(0.4-77.3) \\
\text { n } 1 / 458\end{array}$ & 10.14-18.00 \\
\hline 1996 & $\begin{array}{l}4.83(0.6-57.6) \\
n 1 / 450\end{array}$ & $13.04-22.63$ & $\begin{array}{l}9.20(0.7-79.6) \\
\text { n } 1 / 468\end{array}$ & $16.57-24.77$ \\
\hline 1997 & $\begin{array}{l}6.46(0.2-72.2) \\
n 1 / 439\end{array}$ & 15.80-20.81 & $\begin{array}{l}7.40(0.2-116.9) \\
n 1 / 440\end{array}$ & 18.05-33.13 \\
\hline 1998 & $\begin{array}{l}6.95(0.2-109.2) \\
\text { n } 1 / 458\end{array}$ & 26.13-44.18 & $\begin{array}{l}10.83(0.9-121.3) \\
\text { n } 1 / 479\end{array}$ & 29.35-44.45 \\
\hline 1999 & $\begin{array}{l}5.37(0.1-136.5) \\
\text { n } 1 / 462\end{array}$ & 28.47-43.16 & $\begin{array}{l}10.16(0.3-117.0) \\
\text { n } 1 / 474\end{array}$ & $33.71-46.24$ \\
\hline 2000 & $\begin{array}{l}8.92(0.1-70.3) \\
\text { n } 1 / 487\end{array}$ & $32.72-45.28$ & $\begin{array}{l}9.96(0.2-133.9) \\
n 1 / 493\end{array}$ & 35.99-46.12 \\
\hline
\end{tabular}

Note that sample sizes correspond to birds dispersing from their natal colony. In bold, we marked if the observed distance is significantly below (2.5 percentile) or above (97.5 percentile) the expected values
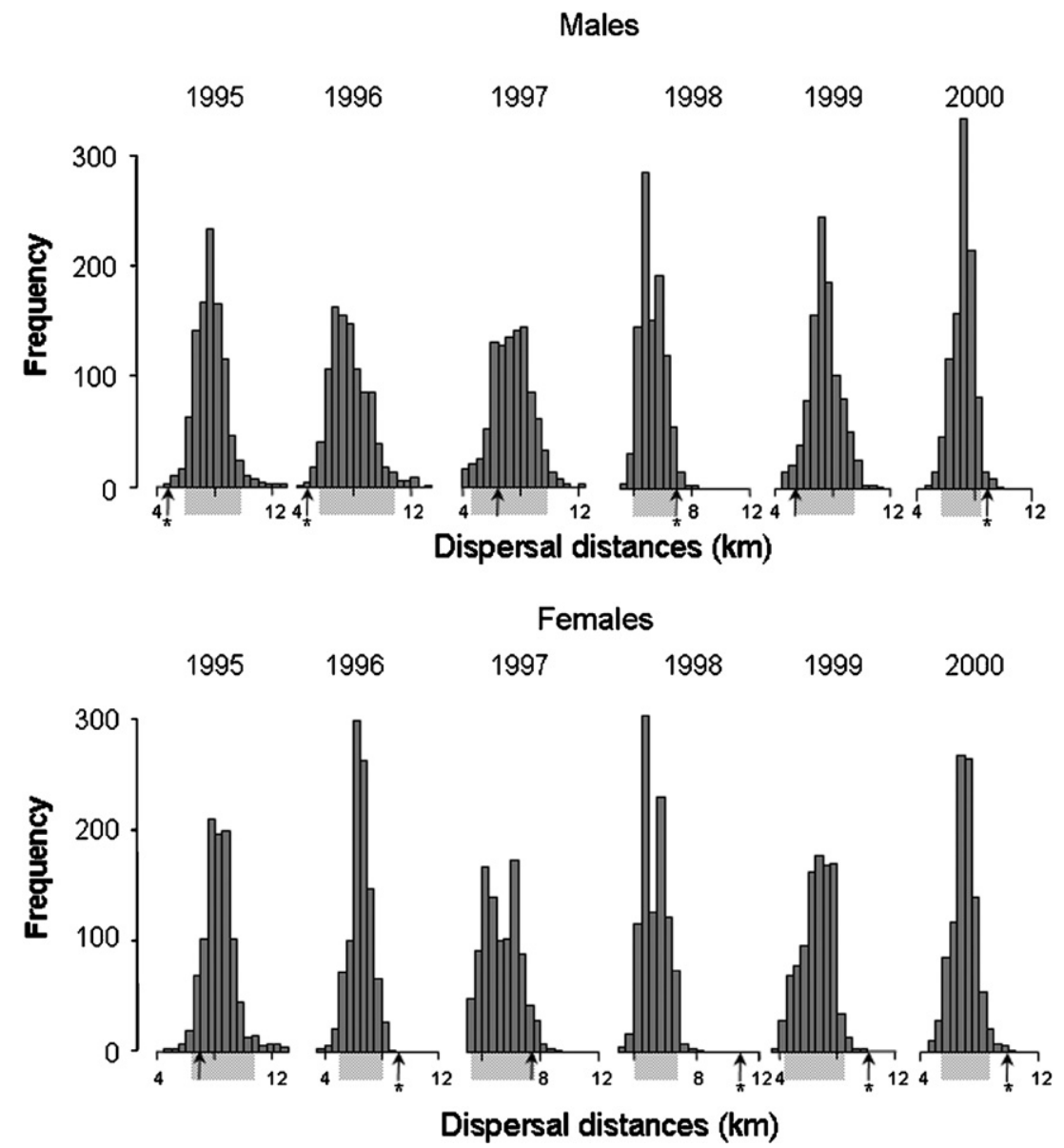

Fig. 2. Frequency distribution of median dispersal distances (in $\mathrm{km}$ ) expected for lesser kestrels that dispersed under the null model of random distribution of individuals within their natal subpopulation. Arrows indicate the observed value for each year. *: po 0.05 .

distances than expected under the random model (although 1999 was marginally significant), while in 2 years (1998 and 2000) dispersal distances were longer than expected, and no differences with the random pattern were obtained in another year (1997). Therefore, we can conclude that at this reduced spatial scale 
dispersing females tend to move more than expected, while males move with inter-year variations around a random pattern of settlement.

\section{Discussion}

Ecological, spatial and social constraints seem to be at least partly responsible for the different dispersal patterns observed among or even within populations of the same species (Bowler \& Benton, 2005). In this sense, particular population circumstances have been suggested to complicate the detection of evolutionary fixed dispersal strategies such as sex-biased dispersal (Serrano et al., 2003). Similarly, optimal dispersal strategies could be difficult to detect under certain ecological scenarios. Frequency distributions of dispersal distances may be determined by the number and spatial distribution of available sites at different distances from the point of origin, which may generate dispersal patterns largely influenced by the ecological, rather than the evolutionary context. Thus, inferences based only on dispersal rates or distances would be misleading. This problem may be exacerbated by methodological limitations of capture-mark-recapture data, which provide information about the final pattern of recruitment, but not about the exact mechanism and movement process underlying individual settlement. In fact, this approach imposes important limitations on our ability to derive inferences regarding the movement stage linking emigration from a given site and immigration to a new one, which may be key to understand individual preferences (Doerr \& Doerr, 2005). Continuous monitoring techniques such as radiotelemetry (e.g. Kenward, Walls, \& Hodder, 2001; Porter \& Dooley, 1993) may help in this sense, but are much less used to study dispersal because they require a great amount of effort and resources if we want to obtain detailed information based on representative sample sizes at relevant spatial and temporal scales.

An intuitively appealing approach to deal with these problems is to compare realized patterns of dispersal with those generated by individuals randomly dispersing among the available sites. This has been used by Greenwood et al. (1979) to demonstrate that natal dispersal patterns of great tits were not influenced by the distance at which a bird could be recovered. This procedure, however, has been seldom used in decades of research on animal dispersal, although the few exceptions have proven to be useful to distinguish between alternative explanations to dispersal patterns. van Noordwijk (1984) demonstrated that resemblance between parents and offspring in the distance moved from site of birth to site of first breeding by great tits, which had been previously interpreted as a heritable trait (Greenwood et al., 1979), could be simply explained by the spatial distribution of nest boxes and random dispersal among them. Sex differences in natal dispersal propensity of these birds were further demonstrated by using the same methodology (van Tienderen \& van Noordwijk 1988). More recently, Baker, Nur, and Geupel (1995) and Winkler et al. (2005) have tried to correct for limited study areas and spatial variation in recapture intensity to assess large-scale dispersal by conducting randomization tests. Here, we stress that contrasting observed with random estimates of dispersal rates and dispersal distances, two classical dispersal traits used for comparative analyses (Paradis et al., 1998; Weatherhead \& Forbes, 1994), is an interesting and informative method to obtain a realistic description of dispersal patterns under spatial constraints in dispersal options, and hence to advance further in the knowledge of dispersal.

As expected, our simulations indicate that lesser kestrels did not settle randomly, in spite of all colonies of the population being at similar distances from their wintering areas. Lesser kestrels showed higher levels of philopatry to their natal colony and, when dispersing, they moved shorter distances than expected from null models of random dispersal within the whole population. As natal dispersal can be viewed in different ways depending on the scale of analysis (Bowler \& Benton, 2005), a parsimonious explanation for this result is that young kestrels tend to return to their subpopulation of origin, and once there, some of them settle in their natal colony just by chance. However, observed philopatry to the natal colony was much higher than expected even if all returning individuals were randomly assigned to a colony within their birth subpopulation. It is worth noting that $26 \%$ of the individuals dispersed between subpopulations (Serrano \& Tella, 2003), but were "forced" to be philopatric to the subpopulation of origin in the set of randomizations, probably explaining why dispersal distances were longer than expected for females and in some years for males. These simulations thus support the idea that selective pressures have favoured philopatry instead of dispersal in lesser kestrels. Our findings are not surprising in view of the detailed information now available about our species model. Lesser kestrel males acquire and defend the breeding resources, which is in agreement with the higher rates of philopatry exhibited by males at a subpopulation scale, and could explain the differences between sexes detected in this study. Moreover, most fledglings are produced in the largest colonies, and most birds try to settle in a large colony for their first breeding attempt, often their natal colony. However, these first recruits are often evicted by residents in a despotic way and relegated to small colonies of lower quality where competition for breeding sites is relaxed (Serrano et al., 2004; Serrano \& Tella, 2007). This key behavioral 
information may satisfactorily explain the high rates of natal dispersal observed in this population, but in the case that such an amount of information had not been compiled, the simple comparison of realized and random dispersal patterns would had suggested us some hypotheses for explaining the disparity of results, and encouraged us to conduct further research in that direction.

Our studied population is a good example of how dispersal strategies in a given species can be partly misinterpreted by only looking at observed dispersal patterns, and how simple randomization tests can help to understand the spatial ecology of dispersal and focus on the adequate hypotheses underlying movement patterns. Although an analysis of fitness pay-offs of dispersal must be addressed to advance in the understanding of the evolution of this behaviour, the approach proposed here provides useful information from which we can center our research effort, avoiding arbitrary divisions such as classifying a species or population as philopatric or dispersive if the median value of dispersal is below or above 10 territories from the natal area (Greenwood \& Harvey, 1982). We therefore encourage the use of simulation procedures, which are now widely available and commonly used in other research areas, as routinely exploratory tests for any studies on animal dispersal, especially for those obtained through capture-mark-reencounter data.

\section{Acknowledgements}

We are grateful to E. Ursua, A. Gajon, R. Lopez, M.G. Forero, J.A. Donazar, O. Ceballos, Y. Menor, F. Hiraldo, J. M. Grande, I. Luque, R. Jovani, L. Bolonio, F.J. Moreno, E. Pelayo, F.J. Sampietro, I. Sanchez, I. Bisson, G. Blanco, C. Sanchez, E. Munoz, M. Villarroel, J.C. Cirera, F. Hernandez, C. Cortazar, J. Blasco, and J.A. Pinzolas, who helped us with the field work. R. Jovani and P. Laiolo offered important suggestions to the manuscript. Financial support was partially provided by collaborative projects with Diputacion General de Aragon (1994-95) and SEO/BirdLife (1998-99).

\section{References}

Baker, M., Nur, N., \& Geupel, G. R. (1995). Correcting biased estimates of dispersal and survival due to limited study area: Theory and an application using wrentits. The Condor, 97, 663-674.

Bennetts, R. E., Nichols, J. D., Lebreton, J.-D., Pradel, R., Hines, J. E., \& Kitchens, W. M. (2001). Methods for estimating dispersal probabilities and related parameters using marked animals. In J. Clobert, E. Danchin, A. A.
Dhondt, \& J. D. Nichols (Eds.), Dispersal (pp. 3-17). Oxford University Press.

Bowler, D. E., \& Benton, T. G. (2005). Causes and consequences of animal dispersal strategies: Relating individual behaviour to spatial dynamics. Biological Review, 80, 205-225.

Clobert, J., Danchin, E., Dhondt, A., \& Nichols, J. D. (2001). Dispersal. Oxford, UK: Oxford University Press.

Dieckmann, U., O’Hara, B., \& Weisser, W. (1999). The evolutionary ecology of dispersal. Trends in Ecology and Evolution, 14, 88-90.

Doerr, E. D., \& Doerr, V. A. J. (2005). Dispersal range analysis: Quantifying individual variation in dispersal behaviour. Oecologia, 142, 1-10.

Forero, M. G., Donazar, J. A., \& Hiraldo, F. (2002). Causes and fitness consequences of natal dispersal in a population of black kites. Ecology, 83, 858-872.

Greenwood, P. J., Harvey, P. H., \& Perrins, C. M. (1979). The role of dispersal in the great tit (Parus major): The causes, consequences and heritability of natal dispersal. Journal of Animal Ecology, 48, 123-142.

Greenwood, P. J., \& Harvey, P. H. (1982). The natal and breeding dispersal of birds. Annual Review of Ecology and Systematics, 13, 1-21.

Hansson, B., Bensch, S., \& Hasselquist, D. (2003). Heritability of dispersal in the great reed warbler. Ecology Letters, 6, 290-294.

Harvey, P. H., Colwell, R. K., Silvertown, J. W., \& May, R. M. (1983). Null models in ecology. Annual Review of Ecology and Systematics, 14, 189-211.

Johnson, M. L., \& Gaines, M. S. (1990). Evolution of dispersal: Theoretical models and empirical test using birds and mammals. Annual Review of Ecology and Systematics, 21, 449-480.

Kenward, R. E., Walls, S. S., \& Hodder, H. (2001). Life path analysis: Scaling indicates priming effects of social and habitat factors on dispersal distances. Journal of Animal Ecology, 70, 1-13.

Krackow, S. (2003). Motivational and heritable determinants of dispersal latency in wild male house mice (Mus musculus). Ethology, 109, 671-689.

Manly, B. F. J. (1991). Randomization and Monte Carlo methods in biology. Chapman \& Hall: New York.

Matthysen, E. (2005). Density-dependent dispersal in birds and mammals. Ecography, 28, 403-416.

Paradis, E., Baillie, S. R., Sutherland, W. J., \& Gregory, R. D. (1998). Patterns of natal and breeding dispersal in birds. Journal of Animal Ecology, 67, 518-536.

Part, T. (1991). Philopatry pays: A comparison between collared flycatcher sisters. The American Naturalist, 138, 790-796.

Pasinelli, G., Schiegg, K., \& Walters, J. R. (2004). Genetic and environmental influences on natal dispersal distance in a resident bird species. The American Naturalist, 164, 660-669.

Peacock, M. M., \& Ray, C. (2001). Dispersal in pikas (Ochotona princes): Combining genetic and demographic approaches to reveal spatial and temporal patterns. In J. Clobert, E. Danchin, A. A. Dhondt, \& J. D. Nichols (Eds.), Dispersal (pp. 43-56). Oxford: Oxford University Press. 
Porter, J. H., \& Dooley, J. L. (1993). Animal dispersal patterns: A reassessment of simple mathematical models. Ecology, 74, 2436-2443.

Serrano, D., Forero, M. G., Donazar, J. A., \& Tella, J. L. (2004). Dispersal and social attraction affect colony selection and dynamics of lesser kestrels. Ecology, 85, 3438-3447.

Serrano, D., Tella, J. L., Donazar, J. A., \& Pomarol, M. (2003). Social and individual features affecting natal dispersal in the colonial lesser kestrel. Ecology, 84, 3044-3054.

Serrano, D., Tella, J. L., Forero, M. G., \& Donazar, J. A. (2001). Factors affecting breeding dispersal in the facultatively colonial lesser kestrel: Individual experience vs. conspecific cues. Journal of Animal Ecology, 70, 568-578.

Serrano, D., \& Tella, J. L. (2003). Dispersal within a spatially structured population of lesser kestrels: The role of spatial isolation and conspecific attraction. Journal of Animal Ecology, 72, 400-410.

Serrano, D., \& Tella, J. L. (2007). The role of despotism and heritability in determining settlement patterns in the colonial lesser kestrel. The American Naturalist, 169, E53E67.
Serrano, D., Oro, D., Ursua, E., \& Tella, J. L. (2005). Colony size selection determines adult survival and dispersal preferences: Allee effects in a colonial bird. The American Naturalist, 166, E22-E31.

Stamps, J. A. (2001). Habitat selection by dispersers: Integrating proximate and ultimate approaches. In $\mathrm{J}$. Clobert, E. Danchin, A. A. Dhondt, \& J. D. Nichols (Eds.), Dispersal (pp. 230-242). Oxford: Oxford University Press.

van Noordwijk, A. J. (1984). Problems in the analysis of dispersal and a critique on its 'heritability' in the great tit. Journal of Animal Ecology, 53, 533-544.

van Tienderen, P. H., \& van Noordwijk, A. J. (1988). Dispersal, kinship and inbreeding in an island population of the Great tit. Journal of Evolutionary Biology, 2, 117-137.

Weatherhead, P. J., \& Forbes, M. R. L. (1994). Natal philopatry in passerine birds: Genetic or ecological influences? Behavioral Ecology, 5, 426-433.

Winkler, D. W., Wrege, P. H., Allen, P. E., Kast, T. L., Senesac, P., Wasson, M. F., et al. (2005). The natal dispersal of tree swallows in a continuous mainland landscape. Journal of Animal Ecology, 74, 1080-1090. 